\title{
大学生におけるパーソナリティ障害特性の Comorbidityの特徵
}

\author{
$\bigcirc$ 市川玲子 ${ }^{1} \cdot$ 望月聡 $^{2}$ \\ ( ${ }^{1}$ 筑波大学大学院人間総合科学研究科 $\cdot 2$ 筑波大学人間系) \\ キーワード：パーソナリティ障害特性, Comorbidity, 自尊感情
}

\begin{abstract}
Characteristics of comorbidity of personality disorder traits in undergraduates
Reiko ICHIKAWA ${ }^{1}$ and Satoshi MOCHIZUKI ${ }^{2}$

( ${ }^{1}$ Graduate School of Comprehensive Human Sciences, Univ. of Tsukuba, ${ }^{2}$ Faculty of Human Sciences, Univ. of Tsukuba)

Key Words: Personality disorder traits, Comorbidity, Self-esteem
\end{abstract}

\section{目的}

現在, DSM-IV-TR(American Psychiatric Association: APA, 2000)において, 10 類型のパーソナリティ障害（以下 PD）が定義されている。個々の PD の概念は，伝統的な PD 類型や記述的精神医学, および精神分析に由来する類型を中 心に, Millon(1981)の PD 理論に由来する概念を加えて措定 された。しかし, 各 PD 類型にはさまざまな起源があるため, 類型間の重なりや異同がしばしば問題視されている(林, 2005)。DSM の分類体系の問題点については, DSM-IV-TR においても「ある種の研究や教育には有用であるが，はっき りと限界があるし，一貫性のある妥当性も示されていない。 しかも, 異なった群の PD を同時にもっていることがしばし ばある」と記されている(APA, 2000 高橋ら訳 2003, p.652)。 Widiger et al.(1991)は, 各 PD 類型について算出された他の PD との合併診断の頻度が，依存性 PD の $69 \%$ から境界性 PD の 96\%と高率であることを明らかにした。

また，これまでに，PD を疾患単位と見なすか，あるいは PD を健常群と臨床群の連続性の間に位置づけるかという議 論がなされてきた(Livesley et al., 1994)。Haslam et al. (2012)や Arntz et al.(2009)は, Taxometric research の知見 から PD に連続性を仮定できることを示唆し，さらに Bagby et al.(2005)は，DSM-IVの PD がそれぞれパーソナリティの Five Factor Model(Costa \& McCrae, 1992)の 5 因子によって 説明されうることを示している。

しかし，PD を連続的に捉えた上で，各 PD 特性間の $\mathrm{Co}^{-}$ morbidity の特徵を明らかにした研究はこれまでに行われて いない。そこで本研究は, 一般大学生を対象とした質問紙調 査を行うことで，境界性・自己愛性・演技性・強迫性・依存 性・回避性 PD 特性間の Comorbidity の様相を明らかにし, これらと PD の全般的診断基準に含まれている自己や他者に 対する認知的特徴との関連を検討することを目的とした。

\section{方 法}

調查対象者：大学生および大学院生 306 名（男性 117 名，女 性 185 名, 不明 4 名; 平均年齢 20.0 歳, $S D=1.93$ )

使用尺度：(1)DSM-IV II 軸パーソナリティ障害のための構造 化面接(Structured clinical interview for DSM-IV axis II personality disorders: SCID-II; First et al., 2000; 高橋・大 曾根訳, 2002)に含まれる「人格質問票」における境界性・自 己愛性・演技性・強迫性・依存性・回避性 PD に関寸る項目。 (2)ローゼンバーグ自尊感情尺度日本語版(桜井, 2000)。(3)社会 的自尊感情尺度(岡村, 2005)。(4)自己価值の随伴性尺度(伊 藤・小玉)。(5)仮想的有能感尺度 ver. 2 (Hayamizu et al., 2004)

\section{結果と考察}

PD 特性の Comorbidity の様相: $6 つ$ つD 特性得点の標準得 点を用いて, Ward 法によるクラスター分析を行った結果，4 クラスターが抽出された。各クラスターの特徵を比較するた めに, 各 $\mathrm{PD}$ 特性得点を従属変数とした分散分析を行った

(Figure 1)。いずれの PD 特性得点についても群間差が見ら
れ, 多重比較の結果, (1) 自己愛性・演技性 PD 特性が高い群 (自己愛・演技群), (2) 全 PD 特性が高い群 (高 PD 特性群), (3)回避性 PD 特性が高い群 (回避群), (4)全 PD 特性が低い 群（低 PD 特性群）が抽出されたことが示された。したがっ て, これら 6 類型の幅広い PD 特性で Comorbidity が見られ ることと，その中でも特に自己愛性・演技性 PD 特性の Comorbidity が顕著に見られることが示唆された。

各クラスターにおける自己認知・対人認知の特徵: 各クラス ターを独立変数とし, 自尊感情, 社会的自尊感情, 随伴性自 尊感情, 他者軽視傾向の各標準得点をそれぞれ従属変数とし た 1 要因分散分析を行った (Figure 2)。多重比較の結果, 自 己愛・演技群と低 PD 特性群は他の 2 群よりも自尊感情得点 が有意に高いこと, 自己愛・演技群は他の 3 群よりも社会的 自尊感情が有意に高いこと, 高 PD 特性群は他の 3 群よりも 随伴性自尊感情が有意に高く, 回避群および低 PD 特性群よ りも他者軽視傾向が有意に高いこと, および自己愛・演技群 は回避群よりも他者軽視傾向が有意に高いことが示された。 したがって, 広範な PD 特性には, 他者に対する否定的な評 価傾向や, 自己価值の外的要因への随伴性の高さが関連して いることが考えられる。また, 自己愛・演技性 PD 特性の Comorbidity には, 対人関係における自己肯定感と他者に対 する否定的認知が関連していることも示唆された。

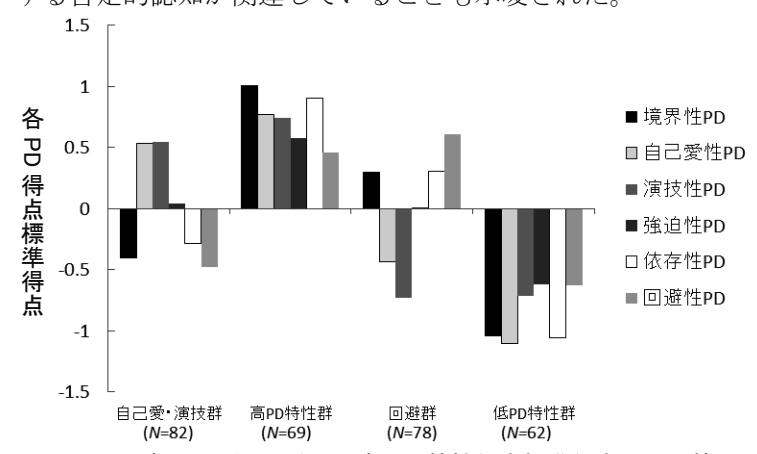

Figure 1 各クラスターにおける各 PD 特性得点標準得点の平均值

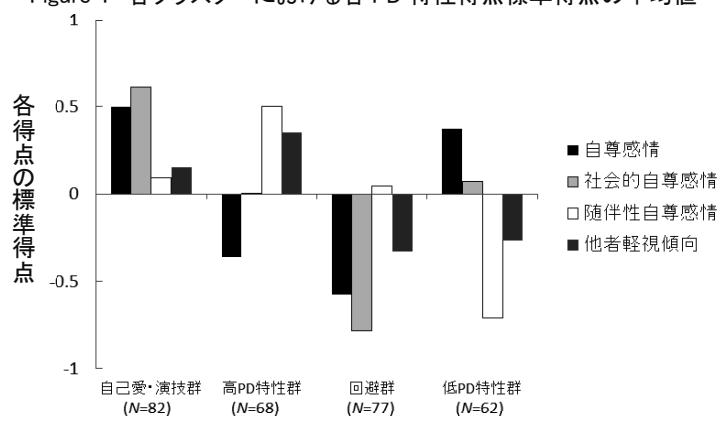

Figure 2 各クラスターにおける各得点の標準得点の平均値 